\title{
CONSILIUM
}

Berkala Kajian Konseling Dan Ilmu Keagamaan

Avalaible at http://jurnal.uinsu.ac.id/index.php/consilium

ISSN : 2338-0608 (Print) | ISSN : 2654-878X (Online)

\section{Efektivitas Layanan Informasi Karir Dalam Meningkatkan Kemampuan Perencaanaan Karir Siswa}

\author{
Djoni Aminuddin ${ }^{1 *}$, Mulyadi $^{1}$
}

${ }^{1}$ Universitas Indraprasta PGRI Jakarta, DKI. Jakarta, Indonesia.

*Korespondensi: djoniaminuddin@gmail.com

\begin{abstract}
This study aims to determine the effectiveness of information services in improving students' career planning skills at SMA Negeri 13 Depok. This research uses a descriptive method with a quantitative approach. The population in this study were all students of class XI in SMA Negeri 13 Depok as many as 77 students who became the study sample using purposive sampling techniques, namely how to take the subject not based on strata, random, or region but based on the existence of certain objectives. The instrument uses a Likert scale. The results showed that information services proved effective in increasing the career planning abilities of students at SMA Negeri 13 Depok. the results of the post test calculation (evaluation of results) showed that the average ability of students' career planning after being given treatment was 93.1818. Based on the results of analysis and hypothesis testing ( $t$ test) shows that there are differences in students' career planning ability before and after information services are provided. This is known from the results of the calculation of the difference between the average ability of career planning students on pre-test with the average ability of career planning on post-test of $-7,15584$. The implications of this study are as a reference for BK teachers that through information services have proven to be effective in improving students' career planning skills.
\end{abstract}

Keywords: Information services, career planning skills

\section{PENDAHULUAN}

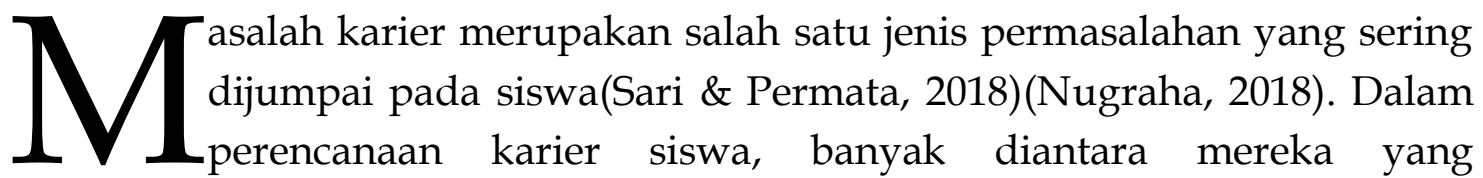
merencanakan hingga membuat keputusan dengan tanpa pertimbangan karena ketidaktahuan siswa itu sendiri mengenai bakat, minat, kemampuan dan lain sebagainya(Permadi, 2013). Lebih lanjut Permadi mengungkapkan berdasarkan hasil pengolahan AUM umum diperoleh hasil 87,7\% peserta didik mengalami 
permasalahan di bidang karir dan pekerjaan. Kemudian dari wawancara yang dilakukan terhadap 15 orang peserta didik kelas X SMA Negeri 1 Padang.

Selanjutnya, Berdasarkan wawancara dan observasi terdahulu yang dilakukan oleh (Fionita \& Reeza Zevty Ratu, 2014)Mahasiswa Bimbingan dan Konseling Universitas Negri Surabaya di SMK Negeri 1 Surabaya menyatakan bahwa hampir 53\% dari siswa kelas XI kompetensi keahlian akuntansi mengalami kebingungan dalam melakukan merencanakan karier mereka meskipun sudah menempati jurusan yang mereka pilih saat ini. Hal ini ditunjang dengan hasil dari penyebaran Alat Ungkap Masalah (AUM) yang dilakukan oleh guru BK pada seluruh siswa kelas XI kompetensi keahlian akuntansi SMK Negeri 1 Surabaya, didapatkan data bahwa permasalahan yang paling tinggi skornya adalah pada aspek karier.

Sedangkan menurut (Hartinah \& Wibowo, 2015), ia menjelaskan bahwa dalam penelitian yang dilakukan oleh Lathifah di SMA Negeri Malang, ia menyimpulkan bahwa kurangnya informasi atau pengetahuan tentang karir ini salah satunya disebabkan oleh kurangnya pengenalan bimbingan atau layanan karir dan penilaian karir sehingga berdampak pada ketidakmandirian siswa dalam menentukan pilihan karir mereka. Apabila informasi dan pemahaman tentang karir sudah dipahami sejak dini, maka diharapkan siswa memiliki keyakinan dalam memilih penjurusan atau program studi di perguruan tinggi maupun memiliki pandangan dalam memilih pekerjaan setelah lulus SMA.

Setiap individu selalu dihadapkan pada banyak pilihan dan diharuskan dapat menentukan sikap pilihannya. Maka dari itu, idealnya seseorang harus memiliki kemampuan perencanaan karier yang tepat sesuai bidang kemampuan atau potensi yang dimilikinya, karena pada dasarnya keputusan karier yang dipilihnya nanti akan menentukan arah hidup dan masa depannya. Sehingga dengan demikian seseorang tersebut matang dalam pemilihan karir (Almuin, Solihatun, \& Haryono, 2017). Remaja sebagai siswa di sekolah menengah, pada masa ini siswa dituntut mampu membuat perencanaan karier yang terkait dengan masa depannya(Supriatna \& Budiman, 2009).

Permasalahan dalam perencanaan karier juga terjadi di SMA Negeri 13 Depok. Hasil studi wawancara terhadap beberapa siswa kelas XI di SMA Negeri 13 Depok, diperoleh informasi masih banyak di sekolah tersebut siswa-siswa yang ketika ditanya rencana setelah lulus jawaban mereka "saya tidak tahu berbuat apa setelah lulus" atau "saya belum membuat rencana setelah lulus sekolah nanti". Berdasarkan hasil wawancara dari beberapa siswa itulah dapat diketahui bahwa masih banyak siswa yang masih bingung merencanakan karier mereka ke depannya. Kemudian peneliti menyebarkan AUM kepada siswa kelas XI dan didapatkan hasil prosentase masalah tertinggi pada setiap kelas yakni di bidang Karir dan Pekerjaan (KDP). 
Dengan demikian, dapat disimpulkan bahwa siswa-siswa tersebut perlu diberikan penanganan khusus untuk meningkatkan kemampuan perencanaan karier mereka. Hal ini dikarenakan karier merupakan suatu bagian hidup yang tidak dapat terpisahkan, perencanaan karier merupakan suatu hal yang hendaknya dilakukan oleh siswa sedini mungkin. Setidaknya siswa memiliki gambaran dan rencana yang baik untuk masa depan yang sesuai yang diinginkan. Selanjutnya, Perencanaan karier merupakan suatu bantuan yang diberikan kepada siswa secara sistematis dalam mengembangkan tujuan dan pemilihan pendidikan ataupun pekerjaan di masa depan. Parsons (dalam Winkel \& Hastuti, 2004: 626-623) merumuskan perencanaan karier sebagai proses yang dilalui sebelum melakukan pemilihan karier. Proses ini mencakup tiga aspek utama yaitu pengetahuan dan pemahaman akan diri sendiri, pengetahuan dan pemahaman akan pekerjaan, serta penggunaan penalaran yang benar antara diri sendiri dan dunia kerja.

Upaya yang dapat digunakan untuk membantu meningkatkan perencanaan karir siswa, dapat diawali dengan memberikan berbagai informasi karir agar siswa dapat memilah dan memilih berbagai informasi tentang diri dan lingkunggannya sehingga siswa dapat merencanakan karir sesuai dengan karakteristik dirinya(Sugiyarto, 2018). Maka untuk meningkatkan kemampuan perencanaan karier siswa digunakan beberapa cara yang efektif, salah satunya adalah layanan informasi(Ummah, 2013).

Layanan informasi sebagai salah satu komponen dalam program bimbingan, yang sekaligus menjadi salah satu layanan bimbingan dan konseling(Widodo, 2009)(Aliman \& Juarsa, 2017). Komponen ini mencakup aneka usaha untuk membekali siswa dengan pengetahuan serta pemahaman tentang lingkungan hidupnya dan tentang proses perkembangan anak muda. Seperti yang dikemukakan oleh Prayitno (2004: 267) bahwa informasi karier pada tingkat SMA memungkinkan siswa untuk memperdalam dan memperluas pemahaman tentang dunia kerja, mengembangkan rencana sementara yang akan menjadi pegangan setamat SMA, dan memiliki pengetahuan tentang pekerjaan tertentu apabila siswa memang menghendaki untuk memegang jabatan itu setamat dari SMA.

Adapun data informasi yang perlu diperoleh dan ditafsirkan siswa dalam membuat perencanaan karier siswa (Winkel, 2004: 685)(Hidayati, 2015): (1) Informasi tentang diri sendiri, (2) Data tentang keadaan keluarga dekat juga dimasukan dalam lingkup informasi tentang gambaran diri sendiri yang sebenarnya merupakan data sosial, (3) Informasi tentang lingkungan hidup yang relevan bagi perencanaan karier. Berdasarkan data informasi tersebut, maka perencanaan karier siswa dapat digunakan dalam meningkatkan kemampuan perencanaan karier siswa. 


\section{METODE PENELITIAN}

Metode penelitian yang digunakan dengan metode penelitian kuantitatif.Bentuk desain dalam penelitian ini adalah eksperimen. Penelitian eksperimen yang digunakan oleh peneliti adalah pre-experimen designs. Bentuk penelitian ini menggunakan one group pre-testpost-test design. Dalam desain ini terdapat pre test (evaluasi awal) sebelum diberi perlakuan dan post test (evaluasi hasil) setelah diberi perlakuan.Populasi dalam penelitian ini adalah seluruh siswa kelas XI di SMA Negeri 13 Depok.

\section{Tabel 1. Sampel Penelitian}

\begin{tabular}{cll}
\hline \multirow{2}{*}{ No. } & \multicolumn{2}{l}{ Kelas XI } \\
\cline { 2 - 3 } & IPA & IPS \\
\hline $\mathbf{1}$ & 33 & 39 \\
\hline $\mathbf{2}$ & 33 & 40 \\
\hline $\mathbf{3}$ & 34 & 39 \\
\hline $\mathbf{4}$ & 34 & 40 \\
\hline $\mathbf{5}$ & 34 & 40 \\
\hline TOTAL & 366 & \\
\end{tabular}

Instrumen dalam penelitian ini menggunakan skala perencanaan karir, teknik skala berisi sejumlah pertanyaan atau pernyataan yang akan dijawab oleh responden, peneliti menyusun sendiri instrumen yang akan digunakan untuk mengetahui kemampuan perencanaan karier siswa. Sebelum menyusun instrumen penelitian, peneliti terlebih dahulu membuat kisi-kisi instrumen yang dibuat berdasarkan teori-teori dari variabel penelitian dan terdiri dari variabel, indikator, dan nomor soal, kemudian disusun menjadi pernyataan. Pernyataan merupakan stimulus yang tertuju pada indikator yang memancing jawaban yang merupakan refleksi dan keadaan diri subjek yang biasanya tidak disadari oleh responden yang bersangkutan format respon yang digunakan dalam instrumen penelitian terdiri dari empat pilihan pertanyaan yang sangat setuju, setuju, tidak setuju, sangat tidak setuju dengan skor 1-4 tergantung dari butir pernyataan 


\begin{tabular}{|c|c|c|c|c|}
\hline \multirow{2}{*}{ No } & \multicolumn{2}{|c|}{ Pernyataan Positif } & \multicolumn{2}{c|}{ Pernyataan Negatif } \\
\cline { 2 - 5 } & Jawaban & Nilai & Jawaban & Nilai \\
\hline 1 & SS & 4 & SS & 1 \\
\hline 2 & S & 3 & S & 2 \\
\hline 3 & TS & 2 & TS & 3 \\
\hline 4 & STS & 1 & STS & 4 \\
\hline
\end{tabular}

Instrumen penelitian tersusun, maka perlu dilakukan uji instrumen yaitu: uji validitas (kesahihan) butir soal instrumen, dan uji reliabilitas (keterhandalan) perangkat soal. Melalui Uji Validitas dan Uji normalitas. Suatu tes atau instrumen dikatakan valid apabila mampu mengukur apa yang diinginkan dan dapat mengungkap data dari variabel yang diteliti secara tepat. Tinggi rendahnya validitas instrumen menunjukkan sejauh mana data yang terkumpul tidak menyimpang dari gambaran tentang validitas yang dimaksud (Arikunto, 2010: 211).Peneliti mengadakan uji coba dengan melihat indikator variabel yang kemudian dikonstruksikan menjadi item-item pernyataan. Uji validitas yang digunakan dalam penelitian ini dengan menggunakan Pearson Product Moment dan dalam mengolah datanya peneliti menggunakan aplikasi SPSS versi 20.

Sesuai dengan validitas, reliabilitas yang digunakan dalam penelitian ini dengan menggunakan rumus Alpha Cronbach. Dalam mengolah datanya peneliti menggunakan bantuan aplikasi SPSS versi 20.

Penelitian ini menggunakan analisis deskriptif persentase dengan menjelaskan hasil perhitungan skor pre test (evaluasi awal) dan post test (evaluasi hasil). Menurut Azwar (2015:126) menyebutkan bahwa analisis deskriptif bertujuan untuk memberikan deskripsi mengenai subjek penelitian berdasarkan data dari variable yang diperoleh dari kelompok subjek yang diteliti dan tidak dimaksudkan untuk pengujian hipotesis.

Teknik analisis deskripsi merupakan teknik analisis data yang dilakukan untuk mengetahui gambaran kemampuan perencanaan karier siswa sebelum diberikan layanan informasi karier dan setelah diberikan layanan informasi karier. Analisis data yang digunakan dalam penelitian ini adalah menggunakan uji-t atau uji beda, yaitu menganalisis variabel Y (perencanaan karier). Analisis statistik data yang digunakan dalam penelitan ini adalah uji perbedaan mean ( $t$ test). Peneliti menggunakan bantuan alat berupa SPSS 20 untuk perhitungannya.

\section{HASIL PENELITIAN DAN PEMBAHASAN}

Berdasarkan hasil penelitian ini akan disajikan mengenai analisis dan pembahasan hasil pengolahan data penelitian yang meliputi deskripsi data, pengujian persyaratan analisis, pengujian hipotesis penelitian, dan interpretasi 
serta pembahasan hasil penelitian. Dalam menganalisis data diarahkan pada pengujian hipotesis, yang diawali dengan deskripsi data penelitian variable.

Hasil perhitungan uji reliabilitas instrumen dengan menggunakan bantuan SPSS versi 20 sebagai berikut :

Tabel 3. Hasil Uji Reliabilitas Instrumen

\begin{tabular}{ll}
\hline Cronbach's Alpha & N of Items \\
\hline .738 & 29
\end{tabular}

Secara keseluruhan diperoleh hasil $r_{\text {hitung }}=0,738$ dengan $\mathrm{N}=29$ pada taraf signifikansi 5\% dan $r_{\text {tabel }} 0,361$. Dengan demikian $r_{\text {hitung }}=0,738>r_{\text {tabel }} 0,361$, sehingga instrumen tersebut dapat dikatakan reliabel. Berdasarkan perhitungan tersebut, maka disimpulkan bahwa skala kemampuan perencanaan karier yang telah diuji cobakan (try out) memiliki reliabilitas yang baik dan skala kemampuan perencanaan karier tersebut sudah baik digunakan sebagai alat pengumpul data dalam penelitian.

Hasil data yang diuji normalitas dengan bantuan SPSS 20 menggunakan uji Kolmogorov-Smirnov didapat hasil sebagai berikut:

Tabel 4. Hasil Uji Normalitas

One-Sample Kolmogorov-Smirnov Test

\begin{tabular}{|c|c|c|}
\hline & & $\begin{array}{l}\text { Unstandardized } \\
\text { Residual }\end{array}$ \\
\hline $\mathbf{N}$ & & 77 \\
\hline Normal Parameters ${ }^{a, b}$ & Mean & 0E-7 \\
\hline & $\begin{array}{l}\text { Std. } \\
\text { Deviation }\end{array}$ & 5.11013978 \\
\hline Most Extreme Differences & Absolute & .183 \\
\hline & Positive & .183 \\
\hline & Negative & -.117 \\
\hline Kolmogorov-Smirnov Z & & 1.604 \\
\hline Asymp. Sig. (2-tailed) & & .012 \\
\hline a. Test distribution is Norn & & \\
\hline b. Calculated from data. & & \\
\hline
\end{tabular}

Analisis output:

Hasil output dari tabel One Sample Kolmogorov-Smirnov Test diperoleh angka probabilitas atau Asymp. Sig (2-tailed). Nilai ini dibandingkan dengan dengan 0,05 (karena menggunakan taraf signifikan 5\%) untuk pengambilan keputusan dengan mengunakan kriteria pengujian sebagai berikut: 
Jika Asymp. Sig (2-tailed )<0,05 maka distribusi data adalah tidak normal. Jika Asymp. Sig (2-tailed) > 0,05 maka distribusi data adalah normal.

Hasil pengujian diperoleh nilai signifikansi Kolmogorov-Smirnov Test sebesar 0,012. Karena nilai Kolmogorov-Smirnov Test lebih besar dari 0,05 (5\%) maka dapat dikatakan bahwa asumsi normalitas terpenuhi.

Uji linearitas digunakan untuk mengetahui hubungan dari data yang diujikan mempunyai hubungan linear atau tidak secara signifikan. Dasar pengambilan keputusan untuk uji linearitas adalah:

Jika nilai Sig.deviation from linearity> 0,05, maka terdapat hubungan yang linear antara variabel bebas dengan variabel terikat

Jika nilai Sig.deviation from linearity< 0,05, maka tidak terdapat hubungan yang linear antara variabel bebas dengan variabel terikat

Uji linear dengan bantuan SPSS 20, didapatkan hasil sebagai berikut:

Tabel 5. Hasil Uji Linearitas

\begin{tabular}{|c|c|c|c|c|c|c|}
\hline \multicolumn{7}{|c|}{ ANOVA Table } \\
\hline & & & $\begin{array}{l}\text { Sum of } \mathrm{df} \\
\text { Squares }\end{array}$ & $\begin{array}{l}\text { Mean } \\
\text { Square }\end{array}$ & $\mathrm{F}$ & Sig. \\
\hline \multirow{5}{*}{$\begin{array}{l}\text { Posttest } \\
\text { Preetest }\end{array}$} & \multirow{3}{*}{$\begin{array}{l}\text { Between } \\
\text { Groups }\end{array}$} & (Combined) & $1635,891 \quad 24$ & 68,162 & 2,801 & ,001 \\
\hline & & Linearity & 916,826 & 916,826 & 37,671 & ,000 \\
\hline & & $\begin{array}{l}\text { Deviation } \\
\text { from Linearity }\end{array}$ & 719,064 & 31,264 & 1,285 & ,224 \\
\hline & \multicolumn{2}{|c|}{ Within Groups } & $1265,564 \quad 52$ & 24,338 & & \\
\hline & \multicolumn{2}{|c|}{ Total } & 2901,455 & & & \\
\hline
\end{tabular}

Berdasarkan hasil uji linearitas diketahui nilai Sig.deviation from linearity sebesar 0,224 >0,05, maka dapat disimpulkan bahwa terdapat hubungan yang linear antara layanan informasi dengan kemampuan perencanaan karier siswa.

Pengujian hipotesis yang peneliti lakukan menggunakan Uji Paired Sample T-Test dengan bantuan SPSS versi 20. Uji paired sampel $t$ test merupakan bagian dari uji hipotesis komparatif atau uji perbandingan. Paired sample test digunakan untuk mengetahui apakah terdapat perbedaan rata-rata dua sampel berpasangan. Hasil uji t diperoleh sebagai berikut : 
Tabel 6. Hasil Uji Paired Sample T Test (Output 1)

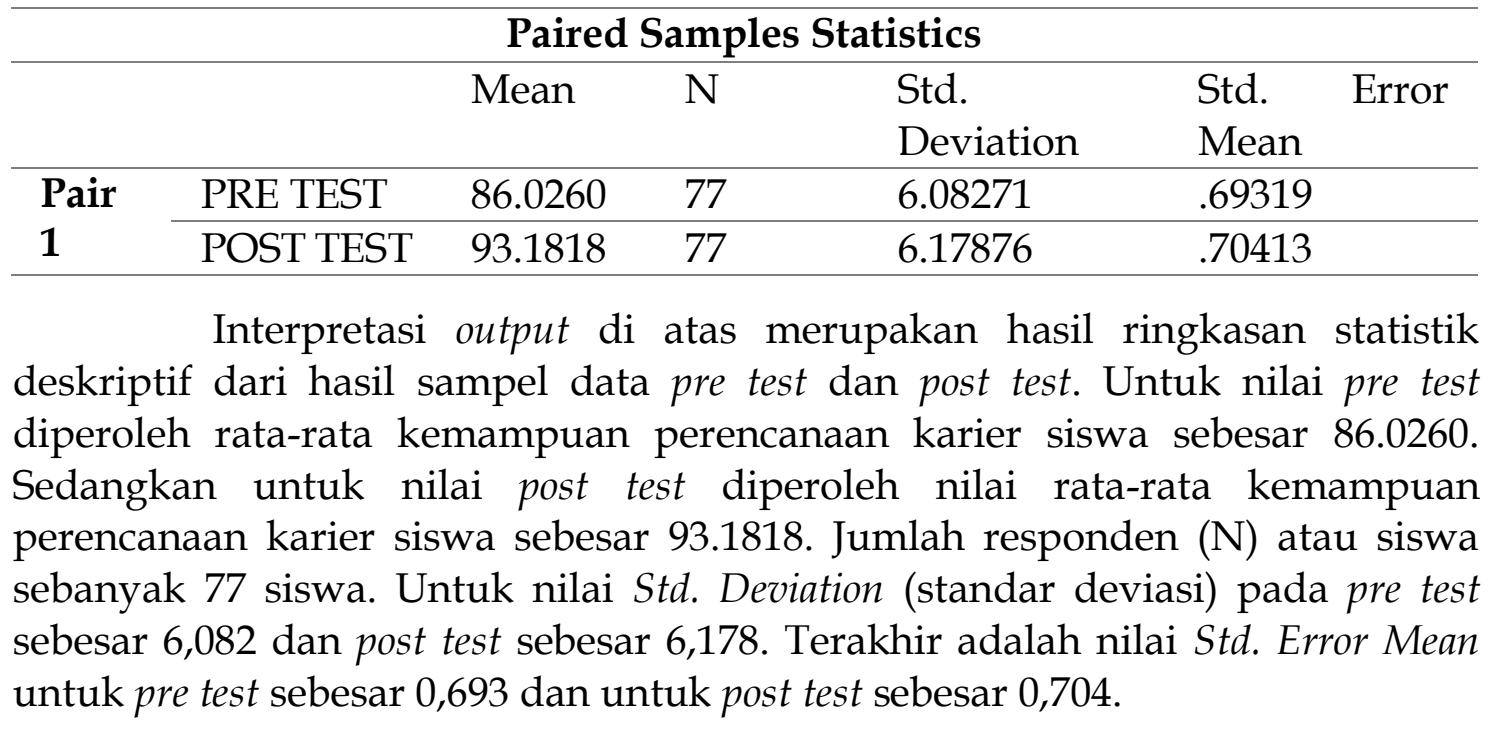

Hasil output ini menunjukan nilai rata-rata kemampuan perencanaan karier siswa pada pre test 86,02 <post test 93,18 yang artinya secara deskriptif ada perbedaan rata-rata kemampuan perencanaan karier siswa antara pre test dengan hasil post test.

\section{Tabel 7. Hasil Uji Paired Sample T Test (Output 2)}

\begin{tabular}{lllll}
\hline \multicolumn{5}{c}{ Paired Samples Correlations } \\
\hline & $\mathrm{N}$ & Correlation & Sig. \\
\hline Pair 1 & PREE TEST \& POST TEST & 77 & .562 & .000 \\
\hline
\end{tabular}

Bagian kedua pada hasil uji paired sample $t$ test (uji t paired) adalah hasil korelasi atau hubungan antara kedua data atau variabel yakni pre test dan post test. Korelasi yang dimaksud disini adalah korelasi pearson product moment. Berdasarkan output di atas diketahui nilai koefisien korelasi (correlation) sebesar 0,562 dengan nilai sig. 0,000. Karena nilai Sig. 0,000<0,05 maka dapat dikatakan bahwa ada hubungan antara pre test dan post test.

Tabel 8. Hasil Uji Paired Sample T Test (Output 3)

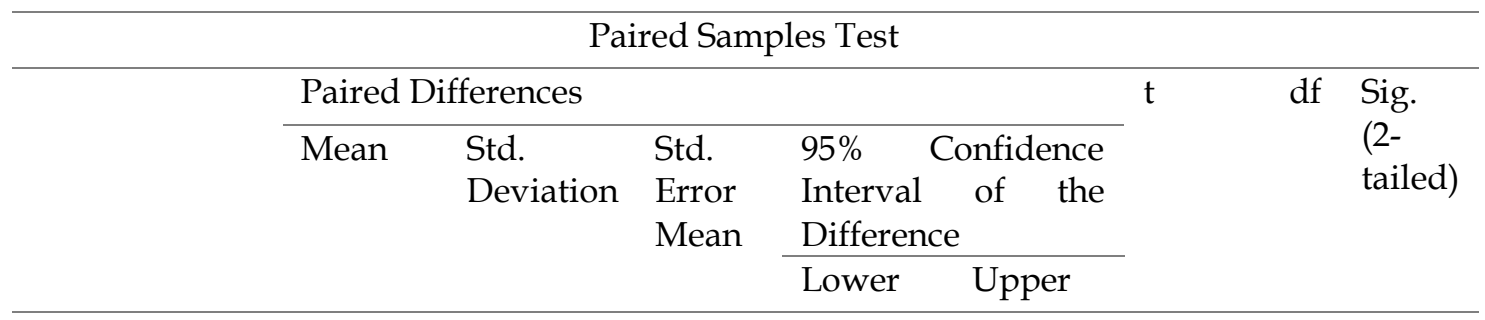




\begin{tabular}{llllllllll}
\hline Pair 1 & PRE & $-7,15584$ & 5,73784 &, 65389 & $-8,45817$ & $-5,85352$ & $-10,944$ & 76 &, 000 \\
& TEST & & & & & & & & \\
& - & & & & & & & & \\
& POST & & & & & & & & \\
& TEST & & & & & & & \\
\hline
\end{tabular}

Bagian output ketiga ini adalah yang terpenting karena pada bagian output ini akan didapatkan jawaban mengenai ada tidaknya perbedaan atau peningkatan kemampuan perencanaan karier siswa sebelum dan setelah dilakukannya layanan informasi karier pada siswa kelas XI IPS SMA Negeri 13 Depok. Hipotesis penelitian dirumuskan sebagai berikut :

Ho : Tidak terdapat peningkatan kemampuan perencanaan karier siswa melalui layanan informasi karier

Ha : Terdapat peningkatan kemampuan perencanaan karier siswa melalui layanan informasi karier

Pedoman pengambilan keputusan dalam uji paired sample t-test berdasarkan nilai signifikansi (Sig.) hasil output SPSS menurut Singgih Santoso (2014 : 265), adalah sebagai berikut:

Jika nilai Sig. (2-tailed)<0,05, maka Ho ditolak dan Ha diterima.

Sebaliknya, jika nilai Sig. (2-tailed)> 0,05, maka Ho diterima dan Ha ditolak.

Berdasarkan tabel output "Paired Samples Test" diketahui nilai Sig. (2tailed) adalah sebesar 0,000 < 0,005, maka Ho ditolak dan Ha diterima. Sehingga dapat disimpulkan bahwa ada perbedaan rata-rata kemampuan perencanaan karier atau dapat dikatakan terdapat peningkatan kemampuan perencanaan karier siswa melalui layanan informasi karier.

Tabel output di atas juga memuat informasi tentang nilai "Mean Paired Differences" sebesar -7,15584. Nilai ini menunjukan selisih antara rata-rata kemampuan perencanaan karier siswa pada pre test dengan rata-rata kemampuan perencanaan karier pada post test atau 86.0260 -93.1818 = -7,15584 dan selisih perbedaan tersebut antara -8,45817 sampai dengan -5,85352(95\% Confidence Interval of the Difference Lower dan Upper). Selanjutnya diketahui $\mathrm{t}$ hitung bernilai negatif yaitu sebesar $-10,944$. Nilai $t$ hitung bernilai negatif disebabkan karena nilai rata-rata kemampuan perencanaan karier siswa pada pre test lebih rendah dari pada rata-rata kemampuan perencanaan karier siswa pada post test. Dalam konteks kasus seperti ini maka nilai t hitung negatif dapat bermakna positif sehingga nilai thitung menjadi 10,944. 


\section{Kesimpulan}

Berdasarkan hasil penelitian diatas dapat disimpulkan bahwa Layanan Informasi karier terbukti efektif dalam meningkatkan kemampuan perencanaan karir siswa di SMA Negeri 13 Depok.

\section{DAFTAR PUSTAKA}

Aliman, A., \& Juarsa, O. (2017). Manajemen bimbingan dan konseling di sma. Manajer pendidikan, 11(3). Retrieved from https:/ / ejournal.unib.ac.id/index.php/manajerpendidikan/article/view/ 3285

Almuin, N., Solihatun, S., \& Haryono, S. (2017). Motivasi pengembangan dan pematangan karir kewirausahaan di pondok pesantren (kajian di pondok pesantren al-rabbani cikeas). Sosio E-Kons, 9(1), 36-45. Retrieved from https://journal.lppmunindra.ac.id/index.php/sosio_ekons/article/view/ 1686

Fionita, A., \& Reeza Zevty Ratu. (2014). Penggunaan genogram untuk meningkatkan kemampuan perencanaan karier siswa kelas xi kompetensi keahlian akuntansi smk negeri 1 surabaya. Jurnal Mahasiswa Bimbingan Konseling UNESA.

Hartinah, G., \& Wibowo, M. E. (2015). Pengembangan model layanan informasi karir berbasis life skills untuk meningkatkan pemahaman dalam perencanaan karir siswa sma. Jurnal Bimbingan Konseling, 4(1).

Hidayati, R. (2015). Layanan informasi karir membantu peserta didik dalam meningkatkan pemahaman karir. Jurnal Konseling GUSJGANG, 1(1). Retrieved from https:/ /jurnal.umk.ac.id/index.php/gusjigang/article/viewFile/258/257

Nugraha, H. (2018). Studi deskriptif tentang perencanaan karir pada siswa kelas xii jurusan teknik informasi-animasi smk muhammadiyah 1 wonosari tahun ajaran 2017/2018. Prodi Bimbingan Dan Konseling Universitas PGRI Yogyakarta. Retrieved from http:/ / repository.upy.ac.id/1669/

Permadi, N. E. (2013). Masalah-masalah yang dihadapi peserta didik dalam perencanaan karir dan implikasinya terhadap pelayanan bimbingan karir. Jurnal Bimbingan Dan Konseling, 1(1), 134-145.

Sari, \& Permata, N. (2018). Pengaruh layanan bimbingan kelompok terhadap kemampuan perencanaan karir pada siswa kelas xii sma swasta islam azizi medan ta 2018/2019. Retrieved from http:/ / digilib.unimed.ac.id/33835/

Sugiyarto, J. (2018). Upaya meningkatkan perencanaan karir peserta didik kelas xii akuntansi smk negeri 1 sragen melalui bimbingan karir dengan 
penggunaan media modul. Edudikara: Jurnal Pendidikan Dan Pembelajaran, 3(3), 275-284.

Supriatna, M., \& Budiman, N. (2009). Bimbingan karir di SMK. Dalam E-Book. Retrieved from http:/ / file.upi.edu/Direktori/FIP/JUR._PSIKOLOGI_PEND_DAN_BIMB INGAN/197102191998021-

NANDANG_BUDIMAN/BIMBINGAN_KARIER_DI_SMK.pdf

Ummah, M. (2013). Penerapan layanan informasi karier untuk meningkatkan kemampuan perencanaan karier siswa kelas xii sman i krembung sidoarjo. Jurnal BK UNESA, 1(1). Retrieved from https://jurnalmahasiswa.unesa.ac.id/index.php/jurnal-bkunesa/article/view/1952

Widodo, B. (2009). Layanan konsultasi orang tua salah satu bidang layanan bimbingan konseling untuk membantu mengatasi masalah anak (sebuah refleksi analitis). Jurnal ilmiah widya warta, 33(1), 1-15. Retrieved from http://jurnalmanajemen.petra.ac.id/index.php/jiw/article/view/17052 